\title{
Local Infiltration Anesthesia in Total Knee and Total Hip Arthroplasty: A Brief Review
}

\author{
Frank M C Van Den Eeden ${ }^{2 *}$ and Yannick N T Van Den Eeden ${ }^{1}$ \\ ${ }^{1}$ Department of Orthopedics, Germany \\ ${ }^{2}$ Van den Eeden Hip Clinic, Belgian Clinics, Belgium
}

Submission: January 06, 2018; Published: February 05, 2018

*Corresponding author: Frank MC van den Eeden, Department of Orthopedics, Van Bossestraat 84 B, 1051 KC Amsterdam, Email: fmcvandeneeden@gmail.com

\begin{abstract}
High-volume local infiltration analgesia (LIA) is widely used in total hip arthroplasty (THA) and total knee arthroplasty (TKA) to reduce postoperative pain and opioid requierments. In TKA this method of postoperative pain treatment seems to be effective. The efficacy of LIA in THA with different approaches to the joint remains unclear. Therefore, we conducted a systematic brief review of randomized clinical trials until June 1, 2017. We investigated LIA for THA and TKA to evaluate the analgesic efficacy of LIA for early postoperative pain treatment. We examined whether intraoperative high-volume LIA in addition to a multimodal oral analgesic regimen, with different approaches for THA would further reduce acute postoperative pain and early opioid requirements consumption.
\end{abstract}

Keywords: Local Infiltration anesthesia; Total hip arthroplasty; Direct anterior approach

\section{Introduction}

Since Kerr \& Kohan [11] in 2008 described the Local Infiltration Anesthesia (LIA) as an affective technique to control acute postoperative pain following total hip (THA) and total knee arthroplasty (TKA), it is widely used to reduce postoperative pain and opioid requierments. Since the length of stay in TKA and THA have diminished, fast recovery and rehabilitation demands an optimized painrelief, allowing early mobilization. The ultimate goal is to achieve adequate pain relief in combination with optimal muscle function. Multi modal analgesia in combination with LIA is meant to reduce the need of opiods and its side effects (nausea, vomiting, reduced gut mobility and urinary retention) to facilitate fast and safe recovery and enhance rehabilitation. The efficacy of this method in THA is still not completely clear.

\section{Methods and Discussion}

In our brief review group until June 2017, we only looked at the randomized studies comparing LIA with saline injections. We evaluated the analgesic efficacy of intra-operative LIA in THA and TKA and the abuse of opioids in the early $(<72 \mathrm{~h})$ postoperative period. Is LIA in combination with multimodal analgesia effective in both hip and knee surgery? In a systematic review of randomized clinical trials in 2014, investigating LIA for TKA and THA, the analgesic efficacy of LIA for early postoperative pain treatment was evaluated [1]. In the TKA group of Andersen \& Kehlet [1], 6 randomized trials [2-6] investigated the analgesic efficacy of LIA compared with saline or no injection. Only two of these trials had low risk of bias. But all six of these trials reported reduced pain scores and less opioid consumption in the early postoperative period (0-32 hrs).

In the THA groupuntil 2017, 5 trials had low risk of bias and in these trials postoperative pain scores were very low and no statistically significant differences in pain scores or opioid requirements were observed in the early post operative period (0-24 hrs). This group was diverse in use of systemic analgesia and surgical approach used to perform a hip replacement and varied from posterior, direct lateral, posterolateral to direct anterior approach. (Andersen L $\emptyset$ et al. [7] (posterior), Lunn et al. 2011, Karen V Andersen et al. [1] (postero-lateral), Den Hartog et al. [8] (anterior approach), Hofstad et al. [9] (direct lateral). Based on these results, you could say that LIA should be recommended in TKA but not in THA. However if deviding the different THA trials into sub groups of type of anesthesia and surgical approach the results are conflicting and the role of LIA in THA surgery still needs to be clarified.

Some studies have reported superior outcome with LIA regarding postoperative analgesia and opioid consumption with different approaches to the joint [10-14] in combination with shortening of the hospital stay $[15,16]$. Other studies reported no additional benefit in analgesic effect or reduction of opioid consumption after a single dose of ropivacaine with epinephrine following THA with different approaches $[1,7,8,17,18]$ (Lunn et al. 2011). A recent systematic review of Johnson et al. [19] showed no 
statistically significant differences between neuraxial and general anaesthesia for mortality, surgical duration, surgical site or chest infections, nerve palsies, postoperative nausea and vomiting, or thromboembolic disease when antithrombotic prophylaxis was used.

Although spinal or epidural anesthesia is concerned to be the golden standard for total hip replacement, the grade of relaxation of the musculature around the hip joint seems to be more profound under general anesthesia $[19,20]$. This effect could reduce operative tissue damage at the surgical site associated with lesser pain, swelling and hematoma [2]. Especially using the tissue sparing direct anterior approach the muscular relaxation could be crucial to diminish postoperative pain and abuse of opioids. In the study of Den Hartog [8] in 2015 using LIA with patients undergoing a DAA THA under spinal anesthesia no clinically relevant effect was seen 4 hours after surgery [7]. If the prolonged anesthetic effect, due to spinal anaesthesia with bupivacaine, plays a role in direct postoperative pain reduction, remains unclear.

\section{Conclusion}

Despite the many studies of LIA in THA, final interpretation is hindered by methodological insufficiencies in most studies, especially because of differences in use of systemic analgesia and surgical approach between groups. However we can conclude that the randomized clinical trials in TKA reported an analgesic efficacy of LIA in the early postoperative period with reduction in opioid requirements. In THA the effect of LIA is questionable and this method seems to have limited additional analgesic value. Further studies are necessary to explore the potential of LIA in the tissue sparing anterior approach and other minimal invasive hip surgery under general anesthesia with an optimal level of relaxation for evaluating the effect on postoperative pain and opioids consumption. In accordance to the efficacy of LIA in TKA, some effect of LIA in tissue sparing THA could be expected after early mobilization in fast track treatment.

\section{References}

1. Andersen Lø, Kehlet H (2014) Analgesic efficacy of local infiltration analgesia in hip and knee arthroplasty: a systematic review. Br J Anaest 113(3): 360-374.

2. Busch CA, Shore BJ, Bhandari R, Ganapathy S, MacDonald SJ, et al. (2006) Efficacy of periarticular multimodal drug injection in total knee arthroplasty. A randomized trial. J Bone Joint Surg Am 88 (5): 959-963.

3. Vendittoli PA, Makinen P, Drolet P, Lavigne M, Fallaha M, et al. (2006) A multimodal analgesia protocol for total knee arthroplasty. A randomized, controlled study. J Bone Joint Surg Am 88(2): 282-228.

4. Andersen Lø, Husted H, Otte KS, Kristensen BB, Kehlet H (2008) Highvolume infiltration analgesia in total knee arthroplasty: a randomized, double-blind, placebo-controlled trial. Acta Anaesthesiol Scand 52 (10): 1331-1335.

5. Andersen LØ, Husted H, Kristensen BB, Otte KS, Gaarn Larsen L, et al. (2010) Analgesic efficacy of subcutaneous local anaesthetic wound infiltration in bilateral knee arthroplasty: a randomised, placebocontrolled, double-blind trial. Acta Anaesthesiol Scand 54 (5): 543548.
6. Essving P, Axelsson K, Kjellberg J, Wallgren O, Gupta A, et al. (2010) Reduced morphine consumption and pain intensity with local infiltration analgesia (LIA) following total knee arthroplasty. Acta Orthop 81 (3): 354-360.

7. Andersen LJ, Poulsen T, Krogh B, Nielsen T (2007) Postoperative analgesia in total hip arthroplasty: a randomized double-blinded, placebo-controlled study on peroperative and postoperative ropivacaine, ketorolac, and adrenaline wound infiltration. Acta Orthop 78(2): 187-192.

8. Den Hartog YM, Mathijssen NM, van Dasselaar NT, Langendijk PN, Vehmeijer SB (2015) No effect of the infiltration of local anaesthetic for total hip arthroplasty using an anterior approach: a randomised placebo controlled trial. Bone Joint J 97-B(6): 734-740.

9. Hofstad JK, Winther SB, Rian T, Foss OA, Husby OS, et al. (2015) Perioperative local infiltration anesthesia with ropivacaine has no effect on postoperative pain after total hip arthroplasty. Acta Orthop 86(6): 654-658.

10. Andersen KV, Lone NikolajsenL, Daugaard H, Andersen NT, Haraldsted $\mathrm{V}$, et al. (2015) Local infiltration analgesia is not improved by postoperative intra-articular bolus injections for pain after total hip arthroplasty. A randomized, double-blind, placebo-controlled study with 80 patients. Acta Orthop 86(6): 647-653.

11. Kerr DR, Kohan L (2008) Local infiltration analgesia: a technique for the control of acute postoperative pain following knee and hip surgery: a case study of 325 patients. Acta Orthop 79(2): 174-183.

12. Murphy TP, Byrne DP, Curtin P, Baker JF, Mulhall KJ (2012) Can a periarticular levobupivacaine injection reduce postoperative opiate consumption during primary hip arthroplasty? Clin Orthop Relat Res 470 (2012): 1151-1157.

13. Kuchálik J, Granath B, Ljunggren A, Magnuson A, Lundin A, et al. (2013) Postoperative pain relief after total hip arthroplasty: a randomized, double-blind comparison between intrathecal morphine and local infiltration analgesia. Br J Anaesth 111(5): 793-799.

14. Tushar Gupta, Nidhi Garg, Mayank Gupta (2014) Local infiltration analgesia following total hip replacement: a review of currentliterature. Chinese Journal of Traumatology 17(5): 293-297.

15. Scott CE, Streit J, Biant LC, Breusch SJ (2012) Periarticular infiltration in total hip replacement: effect on heterotopic ossification, analgesic requirements and outcome. Arch Orthop Trauma Surg 132(5): 703709.

16. Eeden van den YNT, De Turck BJG, Eeden van den FMC (2017) 24 hours stay after hip replacement: Implementation of a patient-centered timebased fast-track program. Acta Orthop 88 (1): 24-28.

17. Solovyova O, Lewis CG, Abrams JH, Grady Benson J, Joyce ME, et al. (2013) Local infiltration analgesia followed byc ontinuous infusion of local anesthetic solution fortotal hip arthroplasty: a prospective, randomized, double-blind, placebo-controlled study. J Bone Joint Surg Am 95(21): 1935-1941.

18. Zoric L, Cuvillon P, Alonso S, Demattei C, Vialles N, et al. (2014) Singleshot intraoperative local anaesthetic infiltration does not reduce morphine consumption after total hip arthroplasty: a double-blinded placebo-controlled randomized study. Br J Anaesth 112(4): 722-728.

19. Johnson RL, Kopp SL, Burkle CM, Duncan CM, Jacob AK, et al. (2016) Neuraxialvs General Anaesthesia for Total Hip and Total KneeArthroplasty. A Systematic Review of Comparative-Effectiveness Research. Br J Anaesth 116(2): 163-176.

20. Andersen KV, Pfeiffer Jensen M, Haraldsted V, Søballe K (2007) Reduced hospital stay and narcotic consumption, and improved mobilization with local and intraarticular infiltration after hip arthroplasty: a randomized clinical trial of an intraarticular technique versus epidural infusion in 80 patients. Acta Orthop 78(2): 180-186. 
This work is licensed under Creative Commons Attribution 4.0 License DOI: $10.19080 / J A I C M .2018 .05 .555662$
Your next submission with Juniper Publishers will reach you the below assets

- Quality Editorial service

- Swift Peer Review

- Reprints availability

- E-prints Service

- Manuscript Podcast for convenient understanding

- Global attainment for your research

- Manuscript accessibility in different formats ( Pdf, E-pub, Full Text, Audio)

- Unceasing customer service

Track the below URL for one-step submission https://juniperpublishers.com/online-submission.php 